UDK 582.632.2:581.4(4)

\title{
VARIJABILNOST NEKIH MORFOLOŠKIH SVOJSTAVA 16 PROVENIJENCIJA EVROPSKE BUKVE (Fagus sylvatica L.)
}

\section{Variability of some morphological characteristics of 16 provenience of the European beech (Fagus sylvatica L.)}

\author{
Ćemal Višnjić ${ }^{1}$
}

\begin{abstract}
The paper includes research on the 9-year-old plants, 16 provenances of the European beech (Fagus sylvatica L.). Experimental area was founded in 1991 with a two-year container seedling beech from Germany, Central and Southern Italy and one from Bosnia and Herzegovina, Slovenia and Romania. The paper studied the morphological characteristics of beech, as follows: height, breast diameter, branching and shape of the tree. In terms of increment, one cannot make the final grades that would secure a better picture of the growth rates of some provenances. Higher growth in height and breast diameter showed provenance from southern Italy (Capracotte, Aspromonte and Riffredo) and Southeast Europe (Maramures and Vlasenica). The better shape and branching of the tree have provenances from Central European areal groups, and they are statistically different from provenances from the southern Italy and South-Eastern Europe, from which it can be concluded that the provenances of Central Europe have better morphological characteristics in relation to relatives from Southern Europe.
\end{abstract}

Key words: beech, provenances, height, breast diameter, branching

\section{Izvod}

Rad obuhvata istraživanja na 9-godišnjim biljakama 16 provenijencija evropske bukve (Fagus sylvatica L.) Eksperimentalna površina je osnovana 1991. sa dvogodišnjim kontejnerskim sadnicama bukve iz Njemačke, srednje i južne Italije i po jedna iz Bosne i Hercegovine, Slovenije i Rumunije. U radu su istraživane morfološke karakteristike bukve i to: visina, prsni prečnik, grananje i forma stabla. U cilju utvrđivanja geografskih tipova bukve, testirane provenijencije su grupisane u četiri areal grupe.

U pogledu prirašćivanja ne mogu se donijeti završne ocjene koje bi dale sigurnu sliku o boljem prirašćivanju pojedinih provenijencija. Najbolji prosječni prirast u visinu i prsni prečnik pokazale su provenijencije iz južne Italije (Capracotte, Aspromonte i Riffredo) i jugoistočne Evrope (Maramures i Vlasenica).

\footnotetext{
${ }^{1}$ Šumarski fakultet Univerziteta u Sarajevu - Faculty of Forestry, University of Sarajevo
} 
Po boljoj formi stabla i grananju provenijencije iz srednjoevropske areal grupe se statistički razlikuju od provenijencija iz južne Italije i jugoistočne Evrope iz čega se može zaključiti da provenijencije iz srednje Evrope imaju kvalitetnije morfološke karakteristike u odnosu na srodnike iz južne Evrope.

Ključne riječi: bukva, provenijencije, visina, prsni prečnik, grananje

\section{UVOD - Introduction}

U svom prirodnom arealu bukva (Fagus sylvatica L.) zauzima površinu od oko 20 miliona hektara (MILESCU I ALEXE, 1967) i jedan je od privredno najznačajnijih lišćara Evrope. Velike površine pod bukvom nalaze se u zemljama Balkanskog poluotoka, Francuskoj, Njemačkoj, Danskoj, Švicarskoj i Italiji.

U Bosni i Hercegovini, prema inventuri šuma na velikim površinama od 1964 do 1968 godine (MATIĆ I DR., 1971), od ukupne površine šuma koja iznosi 2,5 miliona hektara, na čiste sastojine bukve otpada 13,3 \%, na mješovite sastojine jele i bukve sa smrčom oko $22,4 \%$, na bukove panjače i šikare oko 12,6 \%, što znači da je bukva zastupljena u Bosni i Hercegovini na oko 48,3 \% šumske površine. To je čini najzastupljenijom vrstom drveća u našim šumama. Ako se uzmu u obzir samo visoke šume, koje zahvataju površinu od oko 1,1 milion hektara, bukva je u čistim sastojinama ili zajedno sa jelom i smrčom prisutna na oko 900000 hektara, odnosno $82 \%$ površine visokih šuma.

Prema istim podacima, od ukupne zalihe drveta u Bosni i Hercegovini koja iznosi oko 225 miliona kubnih metara krupnog drveta, na bukvu otpada oko $47 \%$. Iz ovih podataka proizlazi da je bukva od velikog značaja za šumarsku privredu Bosne i Hercegovine, ali ne samo kao sirovina u drvnoj industriji, nego i kao faktor očuvanja biodiverziteta i stabilnosti šumskih ekosistema na ovim prostorima.

U Evropi su proteklih desetljeća vršena mnogobrojna istraživanja na provenijencijama bukve radi odabiranja brzorastućih, prilagodljivih i kvantitativno visoko vrijednih sastojina bukve, koje bi bile osnov za buduće obnavljanje i podizanje novih kultura (BRINAR 1963; RZEZNIK, 1976; PAULE 1982; KLEINSCHMIT, 1985; KEINSCHMIT I SVOLBA, 1996; MEKIĆ I DR., 2010). Analizom rezultata ovih istraživanja došlo se do zaključaka da evropska bukva pokazuje veliku morfološku, fenološku i fiziološku raznolikost u svom prirodnom arealu, koja je nastala kao rezultat njenog širenja iz refugija, nakon ledenog doba, prirodne selekcije i antropogenog uticaja.

$\mathrm{U}$ ovom radu istraživane su provenijencije iz gotovo čitavog prirodnog areala bukve, sa težištem usmjerenim ka utvrđivanju razlika u morfološkim osobinama između pojedinih provenijencija. Objekat istraživanja je bila eksperimentalna površina sa 16 provenijencja evropske bukve, od kojih četiri potiču iz Njemačke, devet iz Italije i po jedna iz Slovenije, Bosne i Hercegovine i Rumunije. 


\section{MATERIJAL I METODE ISTRAŽIVANJA - Materials and methods}

Israživanja su provedena na devetogodišnjim sadnicama 16 provenijencija evropske bukve. Sadnice bukve, sa eksperimentalne površine, koje su bile predmet istraživanja proizvedene su iz sjemena koje potiče iz srednje i južne Italije, Njemačke, i jugoistočne Evrope (tabela 1)

Tabela 1. Porijeklo istraživanih provenijencija bukve

Table 1. Origin of the tested beech provenances

\begin{tabular}{|c|c|c|c|c|c|c|c|c|}
\hline \multirow[t]{2}{*}{ R.b. } & \multirow[t]{2}{*}{ Ag.* } & \multirow[t]{2}{*}{$\begin{array}{l}\text { Država } \\
\text { Country }\end{array}$} & \multirow[t]{2}{*}{$\begin{array}{l}\text { Region } \\
\text { Region }\end{array}$} & \multirow[t]{2}{*}{$\begin{array}{l}\text { Provenijencija } \\
\text { Provenance }\end{array}$} & \multirow[t]{2}{*}{$\begin{array}{l}\text { Kratica } \\
\text { Mark }\end{array}$} & \multirow{2}{*}{$\begin{array}{l}\text { Nadm. } \\
\text { vis. } \\
\text { Altitude }\end{array}$} & \multicolumn{2}{|c|}{$\begin{array}{l}\text { Koordinate } \\
\text { Coordinate }\end{array}$} \\
\hline & & & & & & & S.G.Š & I.G.D. \\
\hline 1 & I & Njemačka & FoA Lensahn & 81003 & $L E$ & 70 & $54^{\circ} 13^{\prime}$ & $10^{\circ} 52^{\prime}$ \\
\hline 2 & & & FoA Hasbruch & 81002 & $H A$ & 10 & $53^{\circ} 10^{\prime}$ & $8^{\circ} 15^{\prime}$ \\
\hline 3 & & & FoA Scheßlitz & 81013 & $S Z$ & 400 & $49^{\circ} 59^{\prime}$ & $11^{\circ} 01^{\prime}$ \\
\hline 4 & & & FoA Freising & 81014 & $F R$ & 500 & $48^{\circ} 23^{\prime}$ & $11^{\circ} 44^{\prime}$ \\
\hline 5 & II & Slovenija & Idria & Mrzla Rupa & $S L$ & 900 & $46^{\circ} 05^{\prime}$ & $14^{\circ} 20^{\prime}$ \\
\hline 6 & & Rumunija & Maramures & A 130 & $R 88$ & 800 & $47^{\circ} 08^{\prime}$ & $23^{\circ} 08^{\prime}$ \\
\hline 7 & & $\mathrm{BiH}$ & Vlasenica & Vlasenica & $V L R$ & 670 & $44^{\circ} 11^{\prime}$ & $18^{\circ} 56^{\prime}$ \\
\hline 8 & III & Italija & Potenza & Riffreddo & $R 1$ & 1050 & $40^{\circ} 38^{\prime}$ & $15^{\circ} 49^{\prime}$ \\
\hline 9 & & (Srednja) & Potenza & Lagopesole & $L A$ & 1050 & $40^{\circ} 48^{\prime}$ & $15^{\circ} 45^{\prime}$ \\
\hline 10 & & & Molise & Capracotte & $\overline{C A}$ & 1475 & $41^{\circ} 50^{\prime}$ & $14^{\circ} 16^{\prime}$ \\
\hline 11 & & & Boiano & S.Masimo & $M A$ & 1375 & $41^{\circ} 29^{\prime}$ & $14^{\circ} 29^{\prime}$ \\
\hline 12 & IV & (Južna) & Calabrien & Aspromonte & $C 1$ & 1300 & $38^{\circ} 10^{\prime}$ & $15^{\circ} 50^{\prime}$ \\
\hline 13 & & & Calabrien & Ferdinandea & $C 2$ & 1050 & $38^{\circ} 30^{\prime}$ & $16^{\circ} 22^{\prime}$ \\
\hline 14 & & & Calabrien & Fossiata & $C 3$ & 1500 & $39^{\circ} 03^{\prime}$ & $16^{\circ} 50^{\prime}$ \\
\hline 15 & & & Calabrien & Cinquemiglia & C4 & 1000 & $39^{\circ} 29^{\prime}$ & $15^{\circ} 30^{\prime}$ \\
\hline 16 & & & Sicilien & Tortorici & S1 & 1500 & $38^{\circ} 02^{\prime}$ & $14^{\circ} 49^{\prime}$ \\
\hline
\end{tabular}

(Ag.) *- Arealgrupe (Areal group):

I - Srednja Evropa (CE)

II - Jugoistočna Evropa (SEE)

III - Srednja Italija (CI)

IV - Južna Italija (SI)

Geografska rasprostanjenost provenijencija bukve daje mogućnost svrstavanja provenijencija u četiri grupe, tj. 4 areal grupe kako je prikazano na karti 1.

Proizvedene sadnice 16 provenijencija bukve su zasađene na eksperimentalnoj površini Instituta za uzgajanje šuma u Goettingenu. Radi statističke obrade raspored provenijencija je napravljen po metodi latinskog kvadrata. Razmak između sadnica je 1 metar. Oko eksperimentalne površine zasađen je zaštitni pojas od dva reda sadnica bukve. Od sadnje pa do provođenja istraživanja na toj površini nisu primjenjivane nikakve meliorativne mjere, sadnice nisu prihranjivane niti je vršeno čišćenje bilo koje vrste. 


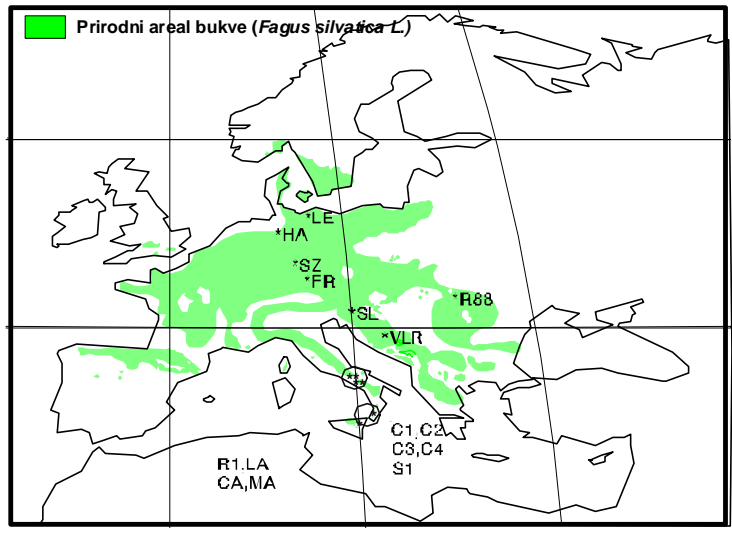

Karta 1. Geografski položaj provenijencija bukve Map 1. Geographic position of beech provenances

Na svim sadnicama su mjereni taksacioni elementi, visina i prsni prečnik, te je utvrđivano rašljanje i forma stabla. Visina je mjerena pomoću letve sa zaokruživanjem na $1 \mathrm{~cm}$. Prsni prečnik je mjeren pomoću prečnice. Kod rašljanja je utvrđivano prisustvo rašlji i broj grana u rašlji, te je za svaku provenijenciju izračunata srednja vrijednost.

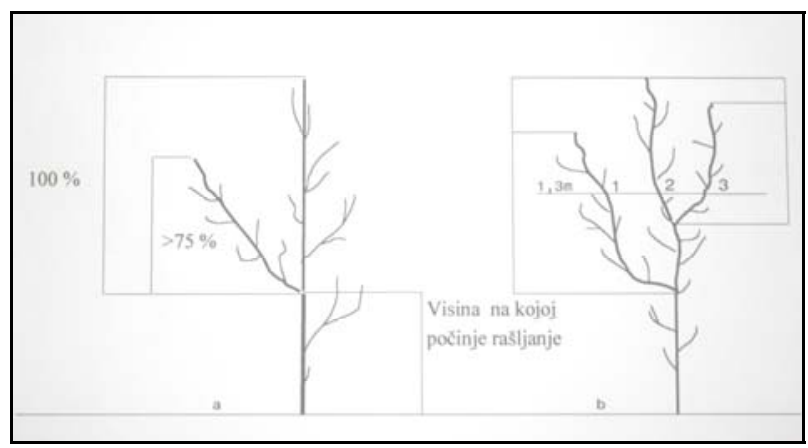

Slika 1. Rašljavost, a) rašljavo stablo, b) rašlje

Figure 1. Branching, a) branching tree, b) branch

Forma stabla je kvantitativni pokazatelj koji je utvrđivan na osnovu izgleda stabala. Kod mladih stabala bukve kategorisana je u pet klasa. U prvu klasu su svrstana dobro razgranata mlada stabalca bukve sa jasno izraženim vretenom, u drugu klasu spadaju dobro razgranata mlada stabalca sa jednom rašljom na visini od 1,3 metara, u treću stabalca koja pokazuju rašljavost sa jednom ili više rašlji koje počinju da se javljaju na visini od $80 \mathrm{~cm}$ od zemlje, u četvrtu stabalca koja pokazuju jaku rašljavost sa više rašlji koje se javljaju na visini od $40 \mathrm{~cm}$ iznad površine tla $\mathrm{i} u$ petu klasu stabalca kod kojih je rašljavost toliko jaka da mlada stabalca imaju dosta vrhova i pokazuju grmoliku formu a rašlje se javljaju već od $5 \mathrm{~cm}$ iznad površine tla. 


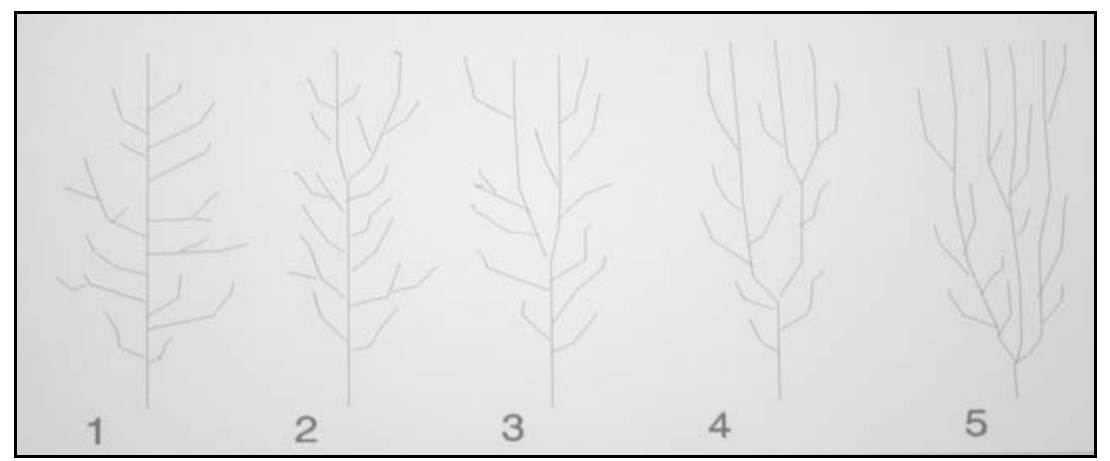

Slika 2. Klasifikacija forme stabla

Figure 2. Classification tree forms

\section{REZULTATI ISTRAŽIVANJA - Results}

\section{Visina - height}

Visine stabala izmjerene ne kraju vegetacionog perioda prikazane su u tabeli 2 kao srednje visine provenijencija. Vertikalne linije svrstavaju provenijencije, u odnosu na ispitivane taksacione elemente, a na osnovu statističke obrade $\mathrm{u}$ jednu grupu. Iz tabele se vidi da provenijencije iz srednje Italije (Capracotte CA, i Riffredo Rl) po visinama odstupaju od ostalih. Provenijencije iz jugoistočne Evrope se po visinama razlikuju, a i okviru samih provenijencija postoji jako variranje visina, tako provenijencija iz Bosne, i pored toga što se svojom srednjom visinom približava vrhu, ima veoma veliki varijacioni koeficijent, što je vidljivo iz tabele 2.

Provenijencije iz srednje Evrope su pokazale dosta slab rast, međutim, kod njih je karakteristično da u okviru provenijencija nema velikih odstupanja visina od aritmetičke sredine kao kod ostalih provenijencija.

I pored velikih razlika $u$ visinama među provenijencijama, koje su $u$ apsolutnom iznosu do 1 metar, one se grupišu u samo tri Dunkan grupe.

Formiranje samo tri Dunkan gupe u ovom slučaju može se objasniti time da su stabla koja su uzeta za ispitivanje mlada (stabalca stara 9 godina), te da u tom periodu postoji jako diferenciranje $i$ različito prirašćivanje stabala $u$ okviru provenijencije.

Treba reći da u ovoj starosnoj dobi kod bukve nije interesantan visinski prirast nego se sve morfološke karakteristike posmatraju kompleksno kako bi zajedno dale jasniju sliku o kvalitativnim karakteristikama pojedinih provenijencija.

U pokušaju da se utvrdi eventualna razlika, odnosno klinalna varijabilnost između populacija u okviru areala bukve, provenijencije su svrstane, kako je već rečeno, u četiri areal grupe. U tebeli 3 su prikazane srednje visine provenijencija grupisanih $\mathrm{u}$ areal grupe. 
Tabela 2. Srednja visina 9-godišnjih provenijencija bukve

Table 2. Average height of 9-year-old beech provenances

\begin{tabular}{|c|c|c|c|c|c|c|}
\hline Rang & Prov. & $\begin{array}{c}\text { Areal } \\
\text { gr. }\end{array}$ & $\mathrm{N}$ & $\begin{array}{c}\text { Visina }(\mathrm{cm}) \\
\text { Height } \\
\end{array}$ & Duncan-Test & $\mathrm{VK} \%$ \\
\hline 1 & HA & $\mathrm{SE}$ & 15 & $194 \pm 49$ & & 25 \\
\hline 2 & R88 & JIE & 15 & $216 \pm 94$ & & 43 \\
\hline 3 & $\mathrm{C} 2$ & $\mathrm{JI}$ & 15 & $239 \pm 84$ & & 35 \\
\hline 4 & $\mathrm{SZ}$ & $\mathrm{SE}$ & 15 & $241 \pm 64$ & & 26 \\
\hline 5 & $\mathrm{C} 4$ & JI & 15 & $243 \pm 49$ & & 21 \\
\hline 6 & S1 & $\mathrm{JI}$ & 15 & $245 \pm 46$ & & 19 \\
\hline 7 & SL & JIE & 15 & $247 \pm 51$ & & 21 \\
\hline 8 & MA & SI & 15 & $261 \pm 89$ & & 34 \\
\hline 9 & LA & SI & 15 & $261 \pm 66$ & & 25 \\
\hline 10 & FR & $\mathrm{SE}$ & 15 & $262 \pm 48$ & & 18 \\
\hline 11 & C3 & JI & 15 & $271 \pm 36$ & & 13 \\
\hline 12 & $\mathrm{LE}$ & SE & 15 & $271 \pm 61$ & & 22 \\
\hline 13 & VLR & JIE & 15 & $273 \pm 94$ & & 34 \\
\hline 14 & $\mathrm{C} 1$ & JI & 15 & $274 \pm 65$ & & 24 \\
\hline 15 & R1 & SI & 15 & $281 \pm 79$ & & 28 \\
\hline 16 & $\mathrm{CA}$ & SI & 15 & $292 \pm 43$ & & 15 \\
\hline \multicolumn{3}{|c|}{$\begin{array}{l}\text { Suma/srednja vrijednost } \\
\text { Sum/average }\end{array}$} & 240 & $254 \pm 67$ & & 26 \\
\hline
\end{tabular}

Tabela 3. Srednja visina provenijencija grupisanih u areal grupe

Table 3. Average height of provenances grouped in areal groups

\begin{tabular}{|c|c|c|c|c|c|c|c|}
\hline Rg. & $\begin{array}{l}\text { Areal grupe } \\
\text { Areal group }\end{array}$ & $\begin{array}{l}\text { Kratica } \\
\text { Mark }\end{array}$ & $\mathrm{N}$ & $\begin{array}{l}\text { Visin } \\
\text { Heigl }\end{array}$ & a $\quad(\mathrm{cm})$ & Duncan-Test & $\mathrm{VK} \%$ \\
\hline 1 & Srednja Evropa & $* \mathrm{SE}$ & 60 & 239 & \pm 61 & & 26 \\
\hline 2 & Jugoist. Evropa & *JIE & 45 & 243 & \pm 82 & & 33 \\
\hline 3 & Južna Italija & $* \mathrm{JI}$ & 75 & 255 & \pm 58 & & 23 \\
\hline 4 & Srednja Italija & $* \mathrm{SI}$ & 60 & 274 & \pm 69 & & 25 \\
\hline \multicolumn{3}{|c|}{$\begin{array}{l}\text { Suma/srednja vrijednost } \\
\text { Sum/average }\end{array}$} & 240 & 254 & \pm 67 & & 26 \\
\hline \multicolumn{2}{|c|}{ *SI } & \multicolumn{3}{|l|}{$* J I$} & *JIE & & *SE \\
\hline \multicolumn{2}{|c|}{ Potenza Riffredo (R1) } & \multicolumn{3}{|c|}{ Kalabrija Aspromonte (Cl) } & $\begin{array}{l}\text { Bosna } \\
\text { Slovenija }\end{array}$ & $\begin{array}{l}\text { Vlasenica }(V L R) \\
\text { Mrzla rupa (SL) }\end{array}$ & $\begin{array}{l}81003(L E \\
81002(H A\end{array}$ \\
\hline \multicolumn{2}{|c|}{ Molise Capracotte (CA) } & \multirow{2}{*}{\multicolumn{3}{|c|}{ Cinquemiglia (C4) }} & Rumunija & A $130(R 88)$ & $81013(S Z)$ \\
\hline \multicolumn{2}{|c|}{ Boiano S.Masimo (MA) } & & & & & & $81014(F R$ \\
\hline
\end{tabular}

Iz tabele 3. se vidi da provenijencije iz areal grupe srednja Italija pokazuju dobar rast, dok provenijencije iz areal grupe južna Italija i provenijencije iz jugoistočnoevropske areal grupe imaju prosječne visine. Provenijencije iz areal grupe srednja Evropa imaju najmanje srednje visine. Provenijencije iz jugoistočne Evrope imaju najjače rasipanje vrijednosti $\mathrm{VK}= \pm 82$. Jedno od objašnjenja ovako velike razlike $\mathrm{u}$ visinama provenijencija 
iz jugoistocne Evrope je velika udaljenost između samih provenjencija koje su svrstane $u$ ovu "areal grupu". Velika udaljenost znači i dosta različite stanišne i klimatske uvjete što sve zajedno utiče na jako diferenciranje među populacijama. Iz tog razloga ova areal grupa je prihvaćena uslovno i koristi za poređenje sa ostalim grupama.

Na osnovu grupisanja areal grupa u Duncanskupine (tabela 2), može se zaključiti da postoje signifikantne razlike u visinama, samo između areal grupe iz srednje Italije $\mathrm{i}$ areal grupe iz srednje Evrope, tj. da provenijencije iz srednje Italije imaju veće visine koje se značajno signifikantno razlikuju u odnosu na provenijencije iz srednje Evrope.

\section{Prsni prečnik - breast diameter}

Srednji prečnik stabala različitih provenijencija je obuhvaćen u tabelama 4 i 5 . Iz tabele 4 se vidi da veće srednje prsne prečnike, u odnosu na ostale, imaju provenijencije iz srednje Italije ( $S$. Masimmo MA $i$ Capracotte $C A$ ). U području sa najmanjim srednjim prečnikom nalaze se srednjoevropske provenijencije (Hasbruch 81002 HA, Schleslitz 81013 SZ), kao i provenijencija iz Rumunije (Maramures R88). Provenijencije sa Kalabrije imaju srednje prsne prečnike koji se kreću od minimalnih (Cinquemiglia C4), pa do onih koje imaju velike srednje prsne prečnike (Fossiata C3).

Tabela 4. Srednji prsni prečnik provenijencija bukve

Table 4. Average breast diameter of beech provenances

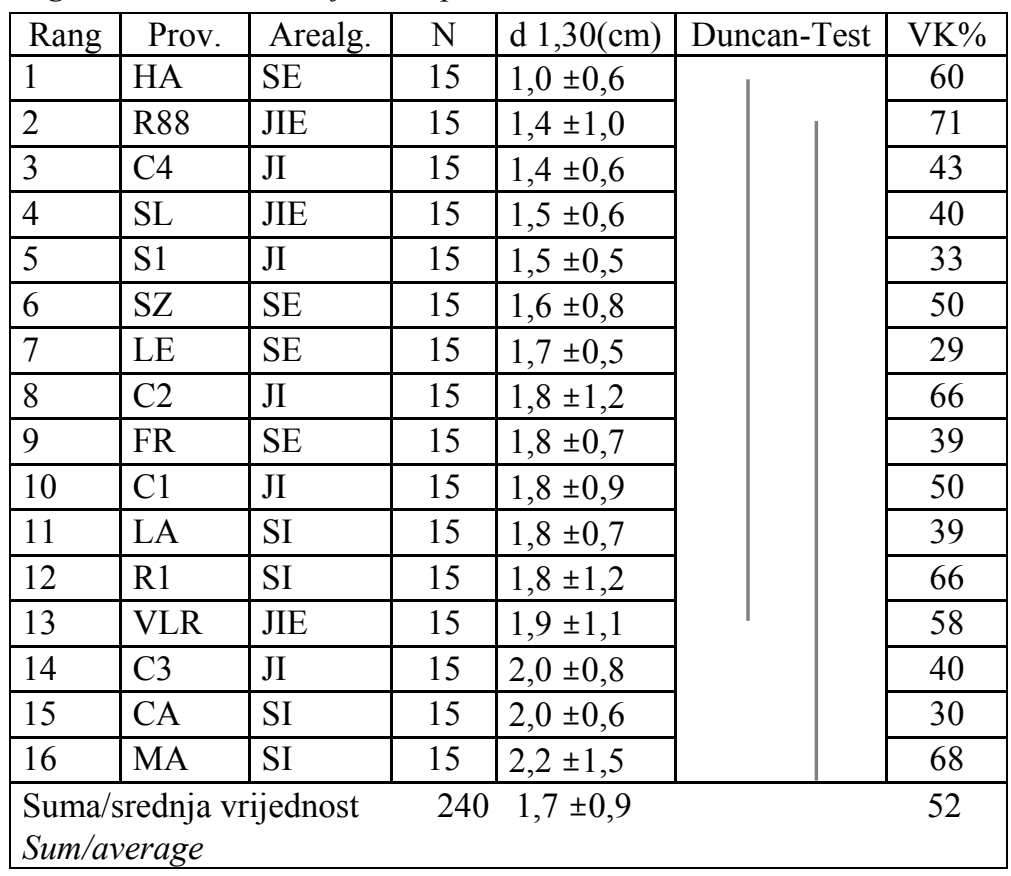

Kao što se vidi iz tabele 4 formirane su samo dvije Duncan grupe. Kao i kod visina tako i kod prečnika, jako rasipanje veličine srednjeg prsnog prečnika u okviru 
jedne provenijencije vodilo je tome da nema velikih signifikantnih razlika u pogledu srednjeg prečnika između provenijencija bukve.

Signifikantne razlike su uočljive samo između provenijencija $S$. Masimmo (MA), Capracotte (CA), Fossiata (C3) u odnosu na provenijenciju iz srednje Evrope (Hasbruch HA).

Tabela 5. Srednji prsni prečnik areal grupa

Table 5. Average breast diameter of areal groups

\begin{tabular}{|c|c|c|c|c|c|c|c|}
\hline Rg. & $\begin{array}{l}\text { Arealgrupe } \\
\text { Arealgroup }\end{array}$ & $\begin{array}{l}\text { Krat. } \\
\text { Mark }\end{array}$ & $\mathrm{N}$ & \multicolumn{2}{|c|}{ d $1.3(\mathrm{~cm})$} & $\begin{array}{c}\text { Duncan- } \\
\text { Test }\end{array}$ & $\mathrm{VK} \%$ \\
\hline 1 & Srednja Evropa & $* \mathrm{SE}$ & 60 & 1,47 & $\pm 0,72$ & & 49 \\
\hline 2 & Jugoist. Evropa & *JIE & 45 & 1,55 & $\pm 0,83$ & & 60 \\
\hline 3 & Južna Italija & $* \mathrm{JI}$ & 75 & 1,69 & $\pm 0,93$ & & 49 \\
\hline 4 & Srednja Italija & *SI & 60 & 1,95 & $\pm 0,99$ & & 50 \\
\hline \multicolumn{3}{|c|}{$\begin{array}{l}\text { Suma/sred.vrijednost } \\
\text { Sum/average }\end{array}$} & 240 & 1,68 & $\pm 0,90$ & & 52 \\
\hline
\end{tabular}

Kao i kod srednjih visina, tako i kod srednjeg prečnika u okviru areal grupa prepoznaju se iste statističke razlike. $U$ oba slučaja diferenciraju se provenijencije iz areal grupe srednja Italija sa najvećim srednjim prsnim prečnikom u odnosu na provenijencije iz areal grupe srednja Evropa koje imaju najmanji srednji prečnik.

Provenijencije iz jugoistocne Evrope pokazuju jaku varijaciju ovog taksacionog elementa, a iz tabele 5 se vidi da varijacioni koeficijent iznosi $60 \%$. Provenijencije iz areal grupe južna Italija pokazuju prosječne vrijednosti srednjeg prsnog prečnika bez posebnih ekstrema.

Stabla koja su uzeta za ispitivanje u okviru jedne provenijencije pokazuju jako variranje u vrijednostima prsnog prečnika. Ovo se može takođe objasniti nedovoljnom starošću ispitivanih provenijencija.

\section{Grananje - branching of beech}

Rezultati broja grana u rašlji (skica 1) dati su u tabeli 6 i 7, kao srednji broj grana u rašlji, odvojeno za svaku provenijenciju i grupisano u areal grupe.

Imajući u vidu da je srednji broj grana koje čine rašlje svega 1,4 može se reći da provenijencija Lensahn (LE), koja pripada areal grupi iz srednje Evrope, ima veoma dobro granjanje. Pored nje i ostale provenijencije iz srednje Evrope, naročito Scheslitz 81013 (SZ) i Hasbruch 81002 (HA), imaju takođe lijepo formirana stabalca sa relativno malim udjelom rašljavosti.

Za razliku od provenijencija iz srednje Evrope, iz tabele 6 je vidljivo da, stabla koja pripadaju provenijencijama sa Kalabrije imaju veliki broj rašlji. Naročito veliki broj grana u rašlji imaju provenijencije Cinquemiglia (C4), i Tortorici (S1). Ove provenijencije su svrstane u "areal grupu" južne Italije i pokazuju signifikantnu razliku u granjanju u odnosu na druge "areal grupe". 
Tabela 6. Granjanje kod provenijencija bukve, $Z^{*}$ - srednji broj grana koje čine rašlju Table 6. Branching of beech provenances, $Z *$ - the average number of branches

\begin{tabular}{|c|c|c|c|c|c|c|}
\hline Rang & Prov. & Arealg. & $\mathrm{N}$ & $Z^{*}$ & Duncan-Test & VK\% \\
\hline 1 & $L E$ & SE & 15 & $1,4 \pm 0,5$ & & 36 \\
\hline 2 & $M A$ & $\mathrm{JI}$ & 15 & $1,6 \pm 1,1$ & & 69 \\
\hline 3 & $S Z$ & SE & 15 & $1,6 \pm 0.9$ & & 47 \\
\hline 4 & $H A$ & $\mathrm{SE}$ & 15 & $1,7 \pm 1,1$ & & 65 \\
\hline 5 & $C 1$ & JI & 15 & $1,7 \pm 1,0$ & & 59 \\
\hline 6 & $R 1$ & SI & 15 & $1,7 \pm 0.9$ & & 53 \\
\hline 7 & $F R$ & $\mathrm{SE}$ & 15 & $1,8 \pm 0,8$ & & 44 \\
\hline 8 & $R 88$ & JIE & 15 & $1,8 \pm 0,7$ & & 39 \\
\hline 9 & $S L$ & JIE & 15 & $1,8 \pm 0,6$ & & 33 \\
\hline 10 & $V L R$ & JIE & 15 & $2,0 \pm 0,8$ & & 40 \\
\hline 11 & $C A$ & SI & 15 & $2,3 \pm 1,0$ & & 43 \\
\hline 12 & $C 2$ & JI & 15 & $2,5 \pm 1,8$ & & 72 \\
\hline 13 & $L A$ & SI & 15 & $2,6 \pm 1,5$ & & 56 \\
\hline 14 & $C 3$ & $\mathrm{JI}$ & 15 & $2,6 \pm 1,7$ & & 65 \\
\hline 15 & S1 & JI & 15 & $3,2 \pm 2,4$ & & 66 \\
\hline 16 & $C 4$ & $\mathrm{JI}$ & 15 & $4,0 \pm 1,6$ & & 40 \\
\hline \multicolumn{3}{|c|}{$\begin{array}{l}\text { Suma/srednja vrijednost } \\
\text { Sum/average }\end{array}$} & 240 & $2,2 \pm 1,5$ & & 66 \\
\hline
\end{tabular}

Rašljanje kod provenijencija iz srednje Italije i jugoistočne Evrope, kako se vidi iz tabele 7 umjereno je bez ekstremnih vrijednosti.

$\mathrm{U}$ apsolutnom iznosu, razlika u srednjem broju rašlji kod provenijencije Lensahn 81003 (LE), koja je rangirana na prvom mjestu i provenijncije sa Kalabrije Cinquemiglia (C4) koja je na zadnjem mjestu je jako velika i iznosi 3,4.

Uprkos velikim apsolutnim razlikama u srednjem broju rašlji među provenijencijama, statističkom analizom i testiranjem signifikantnosti formirane su samo tri Duncan-grupe. Iz tabele 6 je vidljivo da postoje jake signifikantne razlike samo između provenijencija treće Duncan grupe, Cinquemiglia (C4), i Tortorici (S1) u odnosu na ostale provenijencije.

U drugoj Duncan grupi su provenijencije iz južne Italije (Ferdinandea $C 2$, Fossiata C3) kao i dvije provenijencije iz srednje Italije (Lagopesole LA, Capracotte $C A$ ). One pokazuju jaku rašljavost i signifikantno se razlikuju od ostalih provenijencija iz prve Duncan grupe (Lensahn 81003 LE, S. Masimo MA, Scheslitz 81013 SZ, Hasbruch 81002 HA, Aspromonte Cl, Riffreddo R1, Freising 81014 FR, Maramures R88, Mrzla rupa SL, Vlasenica VLR).

I kod poređenja ove veličine između stabala u okviru jedne provenijencije karakteristično je jako rasipanje vrijednosti taksacionog elementa, što je vidljivo na veličini varijacionog koeficijenta. Tako se u okviru jedne provenijencije nalaze stabla sa malim brojem rašlji, odnosno ona koja imaju veći broj. 
Tabela 7. Srednji broj rašljavih grana provenijencija grupisanih u areal grupe, Varijabla (Z) pokazuje srednju vrijednost broja grana koje čine rašlju.

Table 7. The mean number of branches of provenances grouped in areal groups, Variable ( $\left.Z^{*}\right)$ shows the mean number of branches.

\begin{tabular}{|c|c|c|c|c|c|c|}
\hline Rg. & $\begin{array}{l}\text { Arealgrupe } \\
\text { Areal group }\end{array}$ & $\begin{array}{l}\text { Kratica } \\
\text { Mark }\end{array}$ & $\mathrm{N}$ & $Z^{*}$ & $\begin{array}{l}\text { Duncan- } \\
\text { Test }\end{array}$ & $\mathrm{VK} \%$ \\
\hline 1 & Srednja Evropa & $\mathrm{SE}$ & 32 & $1,6 \pm 0,87$ & & 54 \\
\hline 2 & Jugost. Evropa & JIE & 25 & $1,8 \pm 0,69$ & & 38 \\
\hline 3 & Srednja Italija & SI & 36 & $2,2 \pm 1,43$ & & 65 \\
\hline 4 & Južna Italija & JI & 44 & $2,8 \pm 1,86$ & 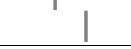 & 66 \\
\hline \multicolumn{3}{|c|}{$\begin{array}{l}\text { Suma/srednja vrijednost. } \\
\text { Sum/average }\end{array}$} & 137 & $2,2 \pm 1,4$ & & 66 \\
\hline
\end{tabular}

Iz tabele 7 je uočljivo da areal grupa srednja Evropa ima najmanji srednji broj grana koje čine rašljavost.

Signifikantne razlike postoje samo između areal grupe srednja Evropa i areal grupe južna Italija koja ima dosta visok srednji broj rašljavih grana.

\section{Forma stabla - form of stem}

Rezultati ocjene "forme stabala" obuhvaćeni su u tabelama 8 i 9. Ovdje su date kvalitativne osobine koje su izražene vrijednostima od 1do 5 a na osnovu klasifikacije mladih stabala bukve (SITTLER, 1981, vidi skicu 2). Vrijednost 1 (jedan) daje se stablima koja imaju izuzetno lijepu formu debla sa jednim vretenom, dok stabla sa brojem 5 (pet) imaju loš oblik debla sa više rašlji i poprimaju grmolik izgled. Utvrđivanje signifikantnih razlika među provenijencijama kod ovog pokazatelja testirano je LSD testom.

Iz tabele se vidi da dobru formu stabla imaju srednjoevropske provenijencije Lensahn (LA), i Freising (FR). Nasuprot njima provenijencije sa Kalabrije, Tortorici (S1) i Cinquemiglia (C4) imaju veoma lošu formu stabla koja se približava žbunastoj. Ove dvije provenijencije se po svojoj formi jako signifikantno razlikuju u odnosu na sve ostale provenijencije.

Za razliku od provenijecije $S$. Masimo $(M A)$, koja pokazuje finu granatost i oblik stabla, ostale provenijencije iz srednje Italije su uglavnom sa formom stabla koja se kreće oko sredine. 
Tabela 8. Forma stabla provenijencija bukve

Table 8. Form of stem of beech provenances

\begin{tabular}{|c|c|c|c|c|c|c|}
\hline Rang & Prov. & Arealg. & $\mathrm{N}$ & $\begin{array}{c}\text { Forma stab. } \\
\text { Form tree }\end{array}$ & LSD-Test & VK\% \\
\hline 1 & $\mathrm{LE}$ & $\mathrm{SE}$ & 15 & $1,7 \pm 1,1$ & & 65 \\
\hline 2 & FR & $\mathrm{SE}$ & 15 & $1,9 \pm 1,1$ & & 58 \\
\hline 3 & MA & SI & 15 & $1,9 \pm 1,5$ & & 79 \\
\hline 4 & HA & $\mathrm{SE}$ & 15 & $2,0 \pm 1,5$ & & 75 \\
\hline 5 & SZ & $\mathrm{SE}$ & 15 & $2,0 \pm 1,3$ & & 65 \\
\hline 6 & R1 & SI & 15 & $2,1 \pm 1,4$ & & 66 \\
\hline 7 & $\mathrm{C} 1$ & JI & 15 & $2,1 \pm 1,3$ & & 62 \\
\hline 8 & VLR & JIE & 15 & $2,4 \pm 1,2$ & & 50 \\
\hline 9 & R88 & JIE & 15 & $2,5 \pm 1,5$ & & 60 \\
\hline 10 & SL & JIE & 15 & $2,6 \pm 1,2$ & & 46 \\
\hline 11 & C3 & JI & 15 & $2,7 \pm 1,5$ & & 55 \\
\hline 12 & $\mathrm{C} 2$ & JI & 15 & $2,9 \pm 1,5$ & & 52 \\
\hline 13 & $\mathrm{CA}$ & SI & 15 & $2,9 \pm 1,4$ & & 48 \\
\hline 14 & LA & SI & 15 & $3.0 \pm 1,3$ & & 43 \\
\hline 15 & $\mathrm{C} 4$ & JI & 15 & $3,4 \pm 1,2$ & & 35 \\
\hline 16 & S1 & JI & 15 & $3,6 \pm 1,1$ & & 30 \\
\hline \multicolumn{3}{|c|}{$\begin{array}{l}\text { Suma/srednja vrijednost } \\
\text { Sum/average }\end{array}$} & 240 & $2,5 \pm 1,3$ & & 55 \\
\hline
\end{tabular}

Sve provenijencije iz jugoistočne Evrope imaju formu stabla koja se kreće od 2,4 do 2,6 8 (skica 2). Treba reći da je jedino kod provenijencije iz Rumunije (Maramures R88) varijacioni koeficijent dosta veliki, što ukazuje na jako rasipanje vrijednosti taksacionog elementa kod stabala u okviru same provenijencije.

Tabela 9. Forma stabla provenijencija u okviru areal grupa

Table 9. Form of stem of beech provenances grouped into areal groups

\begin{tabular}{|c|c|c|c|c|c|c|}
\hline Rg. & $\begin{array}{l}\text { Arealgrupe } \\
\text { Areal group }\end{array}$ & $\begin{array}{l}\text { Krt. } \\
\text { Mark }\end{array}$ & $\mathrm{N}$ & $\begin{array}{l}\text { Forma stabla } \\
\text { Form of stem }\end{array}$ & $\begin{array}{c}\text { LSD- } \\
\text { test }\end{array}$ & $\mathrm{VK} \%$ \\
\hline 1 & Srednja Evropa & $\mathrm{SE}$ & 60 & $1,9 \pm 1,2$ & & 64 \\
\hline 2 & Srednja Italija & JIE & 60 & $2,5 \pm 1,4$ & & 57 \\
\hline 3 & Jugoist. Evropa & SI & 45 & $2,5 \pm 1,2$ & & 50 \\
\hline 4 & Južna Italija & $\mathrm{JI}$ & 75 & $2,9 \pm 1,4$ & & 47 \\
\hline \multicolumn{3}{|c|}{$\begin{array}{l}\text { Suma/srednja vrijednost } \\
\text { Sum/average }\end{array}$} & 240 & $2,5 \pm 1,3$ & & 55 \\
\hline
\end{tabular}

Testiranjem signifikantnosti među provenijencijama svrstanim $u$ areal grupe dobijeni su sljedeći rezultati: 
Areal grupa srednja Evropa ima najbolju formu stabla koja se visoko signifikantno razlikuje od areal grupe južna Italija, a signifikantno se razlikuje od areal grupa srednja Italija i jugoistočna Evropa.

Provenijencije unutar areal grupe srednja Italija i jugoistočna Evropa imaju srednju formu stabla koja se signifikantno razlikuje od forme stabla provenijencija areal grupe južna Italija koje imaju veoma lošu formu stabla.

\section{DISKUSIJA - Discussion}

Sva dosadašnja istraživanja morfoloških karakteristika provenijencija bukve imala su nedostatak koji se ogledao u nedovoljnoj starosti eksperimentalnih površina sa provenijencijama bukve. Porediti prirašćivanje pojedinih provenijencija bilo je $u$ određenoj mjeri ograničeno ako se zna da je bukva vrsta koja ima potrajno prirašćivanje koje ide do starosti. Postignute visine u mladosti ne mogu biti mjera na osnovu kojih bi se moglo tačno utvrditi prirašćivanje pojedinih provenijencija, odnosno dati ocjena koja provenijencija ima najbrži rast, jer često dođe do pomjeranja vrijednosti prirašćivanja u kasnijoj dobi (HoffMAN, 1962).

KLEINSCHMIT (1985) je radeći na eksperimentalnim površinama koje je osnovao Krahl-Urban došao do zaključaka da se ne može sigurno govoriti o populacijama bukve koje brže rastu sve dok stabla na eksperimentalnim površinama ne dosegnu starost od preko 40 godina. On je mjereći visine provenijencija bukve u svim fazama starosti dokazao da mjerenja u ranoj mladosti daju malo pouzdane rezultate. Međutim, po LARSEN-U (1985) na osnovu ranog testa moguće je prognozirati da će pojedine populacije bukve zadržati dobar rast u kasnijoj dobi. Njegova istraživanja govore o tome da bukva, idući od sjevera prema južnom dijelu areala, pokazuje konstantno bolje prirašćivanje. I rezultati istraživanja dobijeni u ovom radu govore da provenijencije iz južnog dijela areala bolje prirašćuju u odnosu na one iz sjevernog dijela.

Dakle, rezultati istraživanja prirašćivanja 16 provenijencija bukve nisu još uvijek pouzdani, ali mogu poslužiti u poređenju i dobijanju zajedničke slike o svim morfološkim karakteristikama pojedinih provenijencija. Iz rezultata rada je vidljivo da provenijencije iz srednje Italije imaju najbolje prirašćivanje za razliku od srednjoevropskih provenijencija, koje su u prosjeku najmanje. Međutim, unutar jedne provenijencije pojedina stabla pokazuju veliku varijabilnost u prirašćivanju. Zbog toga se, na osnovu velike varijabilnosti i nedovoljne starosti ispitivanih provenijencija, ne može zaključiti da će bukve iz srednjoevropskog dijela areala sporije prirašćivati i kasnije.

Gotovo sva istraživanja koja su rađena sa provenijencijama bukve dotiču problem kvalitativnih osobina, naročito pravnosti stabla, rašljanja i forme stabla. Forma stabla je još u ranoj mladosti primjetna (slika 2), te se na osnovu istraživanja na mlađim populacijama bukve i njihovih rezultata mogu donositi određeni zaključci. Rezultati ovog istraživanja takođe govore da postoje velike razlike u kvantitativnim osobinama između pojedinih provenijencija bukve. Provenijencije iz srednje Evrope se $\mathrm{u}$ pogledu forme stabla razlikuju od ostalih provenijencija. One imaju manje rašljavih grana, a forma stabla im je bolja u odnosu na provenijencije iz srednje, južne 
i jugoistočne Evrope. Međutim, ako su grupisane u areal grupe, mogu se konstatovati signifikantne razlike samo između provenijencija iz srednjoevropske areal grupe i provenijencija iz južne Italije, koje imaju veoma lošu formu stabla.

KLEINSCHMITOVI (1985) rezultati ukazuju da se sa povećanjem nadmorske visine mjesta porijekla populacija poboljšava forma i oblik stabla. Ovi rezultati su kasnije potvrđeni u radu KLEINSCHMIT I SVOLBA (1996) koji su provodili istraživanja sa 133 provenijencije bukve. U ovom radu nije uočen jasan geografski trend promjene kvalitativnih svojstava provenijencija sa promjenom geografske širine ili nadmorske visine koji bi ukazivao na postojanje geografskih rasa. Iako provenijencije iz sjevernog dijela areala pokazuju bolju formu stabla u odnosu na južne provenijencije, ne može se zaključiti da postoje značajnije razlike u morfološkim karakteristikama provenijencija bukve koje bi ukazivale na postojanje geografskih rasa.

Provenijencije iz srednje i južne Italije nalaze se na relativno uskom prostoru, ali u visinskom pogledu se dosta razlikuju. Rasprostiru se u rasponu od 1000 do 1800 $\mathrm{m}$ n.v. Pored tako velike visinske razlike, i u pogledu nadmorske visine, ne može se naći nikakav trend koji bi ukazivao na signifikantne razlike u morfološkim svojstvima (forma stabla, grananje) među provenijencijama bukve sa porastom nadmorske visine. $\mathrm{U}$ ovom radu potvrđeni su rezultati mnogobrojnih istraživanja koji ukazuju da kod bukve nema izdiferenciranih geografskih rasa.

Izuzetak ovome su istraživanja URECHIATUA (1992) koji ukazuje na postojanje geografskih rasa bukve u Rumuniji. On obrazlaže da je bukva u Rumuniji prisutna već oko 12000 godina te da je imala dovoljno vremena za diferncijaciju i formiranje geografskih rasa.

U srednjoevropskom dijelu areala bukve nepostojanje geografskih rasa se može objasniti time da je bukva relativno mlada vrsta (srednja Evropa oko 5000 godina) i da je njeno širenje, selekcija i odabiranje u punom zamahu (MUHS I DR., 1992). Ispitivanjem korelacije između prirašćivanja i forme stabla došlo se do rezultata da provenijencije sa manjim prosječnim visinama, a samim tim i manjim prirastom, imaju bolju formu stabla u odnosu na provenijencije sa većim prosječnim visinama.

\section{ZAKLJUČAK - Conclusion}

Rad obuhvata istraživanja na 9-godišnjim biljakama 16 provenijencija evropske bukve (Fagus sylvatica L.) Eksperimentalna površina je osnovana 1991. godine sa dvogodišnjim kontejnerskim sadnicama bukve iz Njemačke, srednje i južne Italije i po jedna iz Bosne i Hercegovine, Slovenije i Rumunije. U radu su istraživane morfološke karakteristike bukve i to: visina, prsni prečnik, grananje i forma stabla. U cilju utvrđivanja geografskih tipova bukve, testirane provenijencije su grupisane $u$ četiri areal grupe.

- Srednjoevropska areal grupa obuhvata provenijencije Hasbruch, Lensahn, Freising i Scheslitz,

- Jugoistočnoevropska areal grupa obuhvata provenijencije Mrzla Rupa, Vlasenica i Maramures, 
- Srednjoitalijanska areal grupa obuhvata provenijencije Riffredo, Lagopesole, Capracotte i Masimo,

- Južnoitalijanska areal grupa obuhvata provenijencije Aspromonte, Ferdinandea, Fossiata, Cinquemiglia i Tortorici.

Na osnovu istraživanja može se zaključiti sljedeće:

U pogledu prirašćivanja ne mogu se donijeti završne ocjene koje bi dale sigurnu sliku o boljem prirašćivanju pojedinih provenijencija. Razlog tome je, kako je navedeno, nedovoljna starost provenijencija bukve, te da $u$ toj dobi provenijencije intenzivno i različito prirašćuju. $U$ ovom istraživanju najbolji prirast u visinu i prsni prečnik pokazale su provenijencije iz južne Italije (Capracotte, Aspromonte, Riffredo) i jugoistočne Evrope (Maramures i Vlasenica).

Najbolje grananje sa najmanjim udjelom rašlji pokazale su provenijencije Lensahn, Maramures, Scheslitz i Hasbruch, dok su najbolju formu stabla imale sve provenijencije iz srednje Evrope (Hasbruch, Lensahn, Freising i Scheslitz), kao i provenijencija Maramures iz jugoistočne Evrope.

Po boljoj formi stabla i grananju provenijencije iz srednjoevropske areal grupe se statistički razlikuju od provenijencija iz južne Italije i jugoistočne Evrope iz toga se može zaključiti da provenijencije iz srednje Evrope imaju kvalitetnije morfološke karakteristike u odnosu na srodnike iz južne Evrope.

\section{LITERATURA - References}

BRINAR, M., 1963: O razvojnem ritmu razlicnih bukovih provenienc oziroma ekotipov. Gozd. Vestn. 21(3-4): S. 65-90

HoffmAN, J., 1962: Die bisherigen Ergebnisse von Buchen- provenienzversuchen. Allgemeine Forstzeitschrift (17), S. 121-123.

KLEINSCHMIT, J., 1985: Results of beech (Fagus sylvatica) provenance experiments in Northern Germany. "Symp. Verbesserung und Waldbau der Buche" in: Mitteilungen der Bundes- forschungsanstalt für Forst- und Holzwirtschaft, Hamburg Nr. 150, S. 65-84.

KLEINSCHMIT, J.; SvolBA, J., 1996: Ergebnisse der Buchenherkunftsversuche von Krahl-Urban. S. 780-782.

KRAHL-URBAN, J., 1958: Vorläufige Ergebnisse von Buchen- provenienzversuchen, Allgemeine Forst- und Jagdzeitung, Bd. 11/12 , S. 42-251.

LARSEN, J. B., 1985: Beech provenances in Denmark. "Symp.Verbesserung und Waldbau der Buche" in: Mitteilungen der Bundesforschungsanstalt für Forst und Holzwirtschaft, Hamburg Nr.150, S. 85-91

Matić, V., Drinić, P., Stefanović, V., Ćirić, M., Beus, V., Bozalo, G., Golić, S., Hamzić, U., Marković, LJ., Petrović, M., Subotić, M., Talović, N., Travar, J., 1971: Stanje šuma u BiH prema inventuri šuma na velikim površinama u periodu 1964-1968. god. Sarajevo, Sumarski fakultet i Institut za šumarstvo u Sarajevu, Posebno izdanje: broj 7. 
MEKIĆ, F., VIŠNJIĆ, Ć., IVOJEVIĆ, S., 2010: Morphological variability of different provenience of beech (Fagus sylvatica L.) in Bosnia and Herzegovina. Regionalni časopis SEFOR.

Milesku, I.; AleXe, A., 1976: "Fagul” Ed. Agrosilvica, Bucuresti, 581 p.

MUHS, H. J.; VON WUELIISCH, G., 1992: Research on improvement of beech in the last decade. Kongress zum Thema "Buche", Pamplona Spanien.

PAULE, L., 1982: Untersuchungen zum Wachstum slowakischer Rotbuchenprovenienzen (Fagus sylvatica L.),Silvae Genetica 31 (4), s. 131-136

RICHTER, J., 1993: Die Buche in Europa. Schriftenreiche der Landesanstalt für Forstwirtschaft Nordheim-Westfalen, Bd 6, S. 1-44.

RZEZNIK, Z., 1976: Badania nad zmiennoscia buka zwyczajnego (Fagus sylvatica L.) polskich proveniencji. Rocz. Akad. roln. Poznan, Bd 72, S. 1-37.

URECHIATU, M., 1992: Beitrag ueber Untersuchungen an 77 Population der rumaenischen Buche. Kongres zum Thema "Buche", Pamplona, Spanien.

\section{Summary}

The paper includes research on the 9-year-old plants, 16 provenances of European beech (Fagus sylvatica L.). Experimental area was founded in 1991 with a two-year container seedling beech from Germany, Central and Southern Italy and one from Bosnia and Herzegovina, Slovenia and Romania. The paper studied the morphological characteristics of beech, as follows: height, breast diameter, branching and shape of the tree. In order to determine the geographic types of beech, the tested provenances were grouped in four areal groups.

- Central European areal group includes provenances: Hasbruch, Lensahn, Freising and Scheslitz,

- The Southeast European areal group includes provenances: Mrzla Hole, Vlasenica and Maramures,

- Central Italian areal group includes provenances: Riffredo, Lagopesole, Capracotte and Masimo,

- South Italian areal group includes provenances: Aspromonte, Ferdinandea, Fossiata, Cinquemiglia and Tortorici.

Based on the research, we can conclude the following:

In terms of increment, one cannot make final grades which would secure a better picture of the growth of provenances. The reason for that lies is the lack of age provenances of beech, and that in this age the provenance have different increment. In this study, the best growth in height and breast diameter were on the provenance from Southern Italy (Capracotte, Aspromonte and Riffredo) and Southeast Europe (Maramures and Vlasenica). The best branching with the smallest number of fork showed provenance Lensahn, Maramures, Scheslitz and Hasbruch, while the best form 
of the tree have all the provenances from Central Europe (Hasbruch, Lensahn, Freising and Scheslitz) and provenance Maramures from Southeast Europe.

Based on better shape and branching on beech provenances from Central European areal groups, they statistically differ from provenances from Southern Italy and Southeast Europe, from which it can be concluded that the provenances from Central Europe have better morphological characteristics in relation to relatives from Southern Europe. 